\title{
Variability of crude protein in crested wheatgrass at defined stages of phenology
}

\author{
RAYMOND F. ANGELL, RICHARD F. MILLER, AND MARSHALL R. HAFERKAMP
}

\section{Abstract}

Variability of crude protein concentration in crested wheatgrass (Agropyron desertorum (Fisch. ex Link)Schult) is an important consideration in the development of grazing programs. Crude protein (CP) concentration in crested wheatgrass was monitored at specific stages of phenology for 5 years. During that time September through August precipitation varied from 68 to $142 \%$ of the 37-year mean. Vegetation was clipped once at 10 phenological stages beginning in April. At the last clipping date, in mid-August, regrowth accumulated after prior clippings was collected. Over the 5-year period, CP of vegetation clipped during mid vegetative growth in late April varied 35\%, relatively, from 14.7\% in 1983 to 9.5\% during 1985 . Even though 1984 crop year precipitation exceeded 1983 by $84 \mathrm{~mm}$, maximum topgrowth biomass was 449 $\mathrm{kg} / \mathrm{ha}$ lower in 1984. Also, CP percentage of vegetative growth in April was 1.8\% lower in 1984 than in 1983. Regrowth CP was positively correlated $(r=0.98)$ with June precipitation, and with the number of rain events in July ( $r=0.97)$. Plants clipped in the boot stage had greater forage CP in August than plants clipped prior to boot stage. However, regrowth biomass was affected by soil water availability and was highly variable. Crude protein in vegetative growth was marginal for growing steers in 1985. Although growing stock are often supplemented in late summer, these data are interpreted to show that spring supplementation may be needed some years.

Key Words: plant nitrogen, precipitation, forage quality, regrowth, Agropyron desertorum

Recent reviews (Malechek 1986, Mayland 1986) discussed factors that affect yield and nutritional quality of crested wheatgrass (Agropyron desertorum (Fisch. ex Link)Schult) and implications for management. One significant factor that affects its management and use is the rapid decline in digestibility and nitrogen content of aerial portions of the plant as the growing season progresses. Crested wheatgrass produces forage high in digestible nutrients in the vegetative stage, but mature, ungrazed plants are deficient in crude protein (CP) (Cook and Harris 1968). Various grazing systems may affect both quantity and quality of forage produced, although increases in quality are often uncertain because of environmental conditions such as soil moisture, temperature, and fertility. Soil nitrogen and water are typically the factors most limiting to plant production in semiarid environments (Charley 1972, Sneva 1977).

Decreased forage quality is expected as plants mature and leaves senesce, however, potential changes in forage quality within a given stage of phenology are not often considered. Variability in nutrient content becomes more important as management intensity increases and forage quality approaches maintenance level for

\footnotetext{
Authors are range scientist, USDA-ARS, and professor, Oregon State University, Eastern Oregon Agricultural Research Center, Burns 97720; and plant physiologist, USDA-ARS. Ft. Keogh Livestock and Range Research Laboratory, Miles City, Montana 59301.

The Eastern Oregon Agricultural Research Center, including Squaw Butte and Union Stations, is jointly operated by USDA Agricultural Research Service and Oregon Agricultural Experiment Station.

Technical Paper No. 8957.

Manuscript accepted 19 July 1989.
}

the class of livestock at pasture. Determination of year to year variation in protein concentration will aid refinement of livestock management programs and result in improved ranch profitability.

Our objectives during this 5-year study were to determine whether changing growing conditions would cause significant variation in CP of crested wheatgrass at 10 defined phenological stages, and to determine, across a range of growing conditions, the CP content of growth produced after clipping at each phenological stage. Crested wheatgrass is well adapted to intensive grazing management; however, if protein concentration varies widely, nutritional deficiencies some years might limit liveweight gains of growing animals.

\section{Materials and Methods}

The study was conducted on the Squaw Butte Experimental Range, $67 \mathrm{~km}$ west of Burns, Oregon. Squaw Butte is located in the northern Great Basin and is characterized as a sagebrush-steppe. The 37-year mean annual precipitation is $284 \mathrm{~mm}$ (Table 1), with most precipitation occurring as snow. The study was conducted on crested wheatgrass pasture which had been moderately grazed in spring since establishment in the late 1960 's. Plots were grazed in late August of 1982 and 1983. Plots have not been grazed since 1983, but were mowed in late August to prevent accumulation of standing dead. Soils are coarse-loamy, mixed, frigid Orthid Durixerols, approximately $55 \mathrm{~cm}$ deep (Lentz and Simonson 1986).

The study was established in fall 1982, as a randomized complete block (RCB) with 10 treatments in 10 blocks. Ten $3 \times 3$ m plots were located in each block. Within each block, 1 quadrat $(1.2 \times 1.8$ m) was clipped in the center of each plot to a 2-cm stubble height at 1 of 10 phenological stages (Table 2). This material is referred to as "initial growth". Harvested material was dried at $60^{\circ} \mathrm{C}$ ground to 1 $\mathrm{mm}$ particle size and stored in closed plastic bags for laboratory analysis. After quadrats were clipped, the remainder of the $3 \times 3-\mathrm{m}$ plot, which served as a buffer, was mowed. In mid August, at the last clipping date, any available regrowth was harvested from the 9 previous treatment plots in each block. Regrowth forage was prepared for analysis as described above. New plots were established each year of the study.

Weather data were recorded daily at a station $0.5 \mathrm{~km}$ from the study site. Precipitation received from September through the following August is reported as crop year precipitation. Samples were analyzed to determine dry matter (DM) after drying at $100^{\circ} \mathrm{C}$ for $24 \mathrm{hr}$, ash after combustion at $500^{\circ} \mathrm{C}$, and kjeldahl nitrogen (AOAC 1980), expressed as crude protein (CP) $(6.25 \times \% \mathrm{~N} ; \mathrm{DM}$ basis).

Split-plot analysis of variance (ANOVA) was used for initial growth and regrowth data, using years as main plots and clipping as subplots (Steel and Torrie 1980). Product-moment correlation coefficients were obtained, using mean $C P$ values from the last 4 clipping dates (anthesis through summer quiescence) of each year, to test whether frequency or amount of precipitation might be related to late summer forage quality. Regression lines for 1987 and pooled data from 1983-86 were compared following procedures of Neter and Wasserman (1974). Statistical significance was 
Table 1. Monthly precipitation (mm) received during the 5-year clipping study, and the 37 year mean and median amounts for the Squaw Butte Experimental Range. Data from 1981-82 are for the crop year just prior to the study.

\begin{tabular}{|c|c|c|c|c|c|c|c|c|c|c|c|c|c|}
\hline $\begin{array}{l}\text { Crop } \\
\text { Year }\end{array}$ & Sept. & Oct. & Nov. & Dec. & Jan. & Feb. & Mar. & Apr. & May & June & July & Aug. & Total \\
\hline $1981-82$ & 11 & 38 & 68 & 80 & 19 & 18 & 12 & 26 & 6 & 35 & 26 & 11 & 350 \\
\hline $1982-83$ & 49 & 20 & 16 & 37 & 12 & 37 & 53 & 19 & 32 & 10 & 19 & 17 & 320 \\
\hline $1983-84$ & 15 & 27 & 45 & 86 & 4 & 11 & 66 & 27 & 17 & 37 & 15 & 53 & 404 \\
\hline $1984-85$ & 2 & 45 & 35 & 5 & 22 & 12 & 13 & 12 & 27 & 4 & 7 & 8 & 194 \\
\hline $1985-86$ & 38 & 12 & 15 & 32 & 26 & 79 & 30 & 10 & 36 & 8 & 3 & 1 & 291 \\
\hline $1986-87$ & 41 & 8 & 19 & 8 & 20 & 25 & 25 & 28 & 34 & 28 & 41 & 8 & 286 \\
\hline Median & 11 & 20 & 26 & 31 & 28 & 18 & 23 & 17 & 27 & 19 & 6 & 9 & 274 \\
\hline Mean & $\begin{array}{l}11 \\
14\end{array}$ & 23 & $\begin{array}{l}20 \\
31\end{array}$ & 35 & $\begin{array}{l}20 \\
34\end{array}$ & $\begin{array}{l}10 \\
23\end{array}$ & 24 & 20 & 31 & 24 & 9 & 16 & 284 \\
\hline
\end{tabular}

Table 2. Crude protein $(\%)$ in crested wheatgrass clipped once between early vegetative and summer quiescence stages from 1983 to 1987 at the Squaw Butte Experimental Range.

\begin{tabular}{|c|c|c|c|c|c|c|c|}
\hline \multirow{2}{*}{$\begin{array}{l}\text { Trt. } \\
\text { no. }\end{array}$} & \multirow{2}{*}{$\begin{array}{l}\text { Approx. } \\
\text { clip } \\
\text { date }\end{array}$} & \multirow[b]{2}{*}{ Phenology } & \multicolumn{5}{|c|}{ Year } \\
\hline & & & 1983 & 1984 & 1985 & 1986 & 1987 \\
\hline & & & $\ldots$ & $\ldots$ & (CP\%) & $\ldots$ & $\ldots$ \\
\hline 1 & mid Apr. & early veg. & 14.4 & 12.9 & 10.6 & 10.7 & 10.9 \\
\hline 2 & late Apr. & mid veg. & 14.7 & 11.9 & 9.5 & 11.2 & 12.2 \\
\hline 3 & mid May & late veg. & 13.6 & 11.6 & 9.4 & 10.5 & 11.1 \\
\hline 4 & late May & early boot & 10.9 & 10.5 & 8.6 & 9.3 & 9.2 \\
\hline 5 & early June & late boot & 7.8 & 8.5 & 7.0 & 7.8 & 8.8 \\
\hline 6 & late June & flowering & 6.4 & 7.2 & 5.5 & 6.0 & 8.3 \\
\hline 7 & early July & anthesis & 4.9 & 5.1 & 4.3 & 4.8 & 6.9 \\
\hline 8 & late July & seed form. & 3.6 & 3.9 & 3.8 & 4.2 & 6.9 \\
\hline 9 & early Aug. & seed set & 3.3 & 3.5 & 3.6 & 3.7 & 6.8 \\
\hline 10 & mid Aug. & $\begin{array}{l}\text { summer } \\
\text { quies. }\end{array}$ & 3.1 & 3.1 & 3.3 & 3.6 & 6.5 \\
\hline
\end{tabular}

Standard errors: year, 0.07 ; clipping date, 0.11 ; year $\times$ clipping date, 0.24 .

accepted at $P<0.05$.

\section{Results}

Crop year (September through August) precipitation varied from $68 \%$ to $142 \%$ of normal (Table 1), with 1983 and 1984 receiving $114 \%$ and $142 \%$ of the 37 -year average. Additionally, crop year precipitation in 1982 , just prior to the study, was $124 \%$ of average. The 1985 crop year was only $68 \%$ of average, and ended a 3-year period of above-average precipitation. Precipitation in 1986 and 1987 was 102 and $101 \%$ of average, respectively. The summer of 1987 was unique because July precipitation exceeded $40 \mathrm{~mm}$. That is the greatest amount on record for July, and approximately 4 times the average. Soil water potential in the $2-20 \mathrm{~cm}$ depth was near $-0.03 \mathrm{MPa}$ in mid April except in 1985 and 1987. Those years soil water potential was about $-0.2 \mathrm{MPa}$ (Miller et al. 1990).

\section{Initial Growth}

Clipping date by year interaction was significant. This indicated that changes in CP concentration associated with any given phenology were affected by environmental conditions each year. Summer precipitation allowed plants to retain green tissue through August in 1987. That year, forage quality in July and August (seed formation to quiescence) was almost twice that observed in all previous years: approximately $7 \%$. Additionally, forage quality was high in April 1983, when plants clipped at the mid vegetative stage in 1983 contained $14.7 \%$ CP (Table 2). We were not able to identify specific environmental effects which caused this variation in quality of early growth; however, precipitation and yield data from 1983 and 1984 may provide insight. Crop year precipitation was $84 \mathrm{~mm}$ greater in 1984 than 1983; however, peak standing crop was $449 \mathrm{~kg} / \mathrm{ha}$ lower in $1984(2,338$ vs. $1,889 \mathrm{~kg} / \mathrm{ha})$ (Table 3). Also, CP percentage in April was 12.9\% in 1984 vs. $14.7 \%$ in 1983.

Forage protein declined rapidly at each clipping from early boot to flowering, until seed formation in late July. Such a decline is typical (Bedell 1973, Hyder and Sneva 1963, Malechek 1986), but in the present study, significant interaction with years occurred in response to changing environmental conditions.

Linear regression analysis of pooled data (1983-86) showed a strong linear relationship between phenology and $C P\left(R^{2}=0.88\right)$, as did data from $1987\left(R^{2}=0.89\right)$ (Fig. 1). However, the 2 regression models were significantly different $(P<.01)$, and the slope of the

Table 3. Crested wheatgrass yield (kg/ha) when clipped at the indicated phenological stage (1st clipping), and regrowth (kg/ha) accumulated between that clipping and mid August (2nd clipping). Plants clipped during summer quiescence were clipped only once.

\begin{tabular}{|c|c|c|c|c|c|c|c|c|c|c|}
\hline \multirow[b]{3}{*}{ Phenological stage } & \multicolumn{10}{|c|}{ Year } \\
\hline & \multicolumn{2}{|c|}{1983} & \multicolumn{2}{|c|}{1984} & \multicolumn{2}{|c|}{1985} & \multicolumn{2}{|c|}{1986} & \multicolumn{2}{|c|}{1987} \\
\hline & lst & 2nd & lst & 2nd & lst & 2nd & 1st & 2nd & lst & 2nd \\
\hline Early vegetative & 273 & 1839 & 87 & 1239 & 227 & 496 & 423 & 765 & 374 & 607 \\
\hline Mid vegetative & 276 & 1524 & 290 & 1365 & 382 & 430 & 498 & 616 & 456 & 402 \\
\hline Late vegetative & 388 & 1540 & 375 & 916 & 444 & 430 & 677 & 376 & 580 & 235 \\
\hline Early boot & 755 & 568 & 646 & 230 & 487 & 319 & 819 & 125 & 814 & 216 \\
\hline Late boot & 1219 & 269 & 1090 & 118 & 913 & 85 & 1102 & 5 & 691 & 164 \\
\hline Early flowering & 1709 & 217 & 1008 & 74 & 1002 & 6 & 1227 & 0 & 818 & 102 \\
\hline Anthesis & 2338 & 72 & 1505 & 43 & 972 & 0 & 1177 & 0 & 775 & 75 \\
\hline Seed formation & 2240 & 0 & 1755 & 0 & 972 & 0 & 1150 & 0 & 787 & 44 \\
\hline Seed set & 2133 & 0 & 1889 & 0 & 835 & 0 & 1204 & 0 & 730 & 0 \\
\hline Summer quiescence & 1966 & - & 1704 & - & 725 & - & 1130 & - & 731 & - \\
\hline
\end{tabular}

First clipping standard errors: year, 18.9; phenology, 23.89; $\mathrm{y} \times$ phen., 53.3.

Regrowth standard errors: year, 33.6; phenology, 31.6; $y \times$ phen., 70.6

Regrowth data adapted from Miller et al. (1990). 


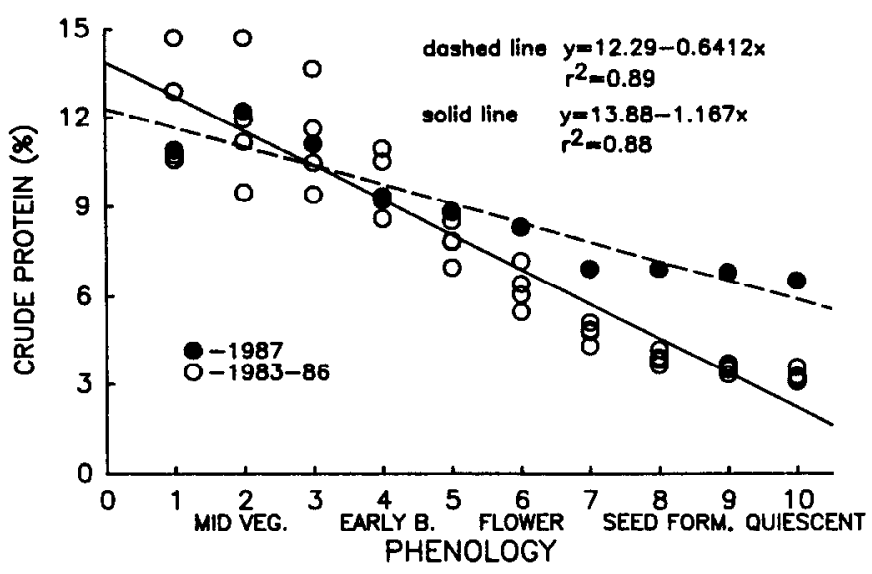

Fig. 1. Regression analysis of the relationship between phenological stage at clipping and mean $C P$ content $(n=10)$ of crested wheatgrass topgrowth. Phenology is on a scale from 1 to 10 as per Table 2. Regressions for pooled data and 1987 data are different $(P<0.01)$, and have different slopes.

1987 model was less than for the pooled model $(P<.05)$. Second and third degree polynomials did not significantly improve fit for either model. Summer precipitation in 1987 promoted growth and delayed loss of quality in crested wheatgrass.

Early to mid summer (June or July) total precipitation was not significantly correlated with plant $\mathrm{CP}$ from anthesis to quiescence stages. However, the number of rainy days in July, was correlated with CP concentration at those phenological stages $(r=0.96, n=5)$. Rain occurred on 7 days in July 1987,1 of which exceeded $26 \mathrm{~mm}$. Fisher et al. (1987) and Charley (1972) have discussed the potential of small precipitation events for stimulating nitrogen mineralization in surface soil, thereby increasing nitrogen availability for use during periods of effective rainfall. If rain events are assumed to be separated in time by at least 1 day, there were 6 events in June and July, 1987, of which only 2 exceeded 10-mm.

\section{Regrowth}

Regrowth of crested wheatgrass after clipping once during the growing season was highly variable (Table 3 ). Regrowth CP in plots clipped on the first 4 dates were analyzed by ANOVA and main effects were highly significant. However, interaction between year and clipping date was also significant. Summer, 1987, precipitation promoted growth and allowed plants to maintain green tissue in August, even for plants clipped prior to elevation of apical meristems in May. Plants clipped on the first 3 dates in 1983 and 1984 contained less than $4 \%$ CP, while those clipped in 1985-86 averaged $4 \%$, and topgrowth from 1987 averaged $8.4 \%$.

Regrowth occurred after 7 clipping dates in 1983 and 1984 and after 8 dates in 1987. Stepwise regression analysis indicated that data from 1983 and 1984 was best described by a cubic polynomial (Fig 2). Data from 1987, however, was best described by a simple quadratic equation after linear and cubic terms were determined to be nonsignificant $(P<.05)$. The first 2 years, crop year precipitation was above normal, while 1987 had a drier than average winter, followed by normal to above-average growing season precipitation.

Regrowth yield in August for plants clipped in spring or summer was also highly variable (Table 3). The first year (1983) was not the wettest year of study, but regrowth was substantial. Below-average precipitation in the 1984-85 crop year limited regrowth even on plots clipped during early vegetative growth. Winter precipitation in 1985-86 allowed more regrowth on plots clipped in April and May; however, below-average June rainfall apparently limited regrowth on plots clipped later in the growing season.

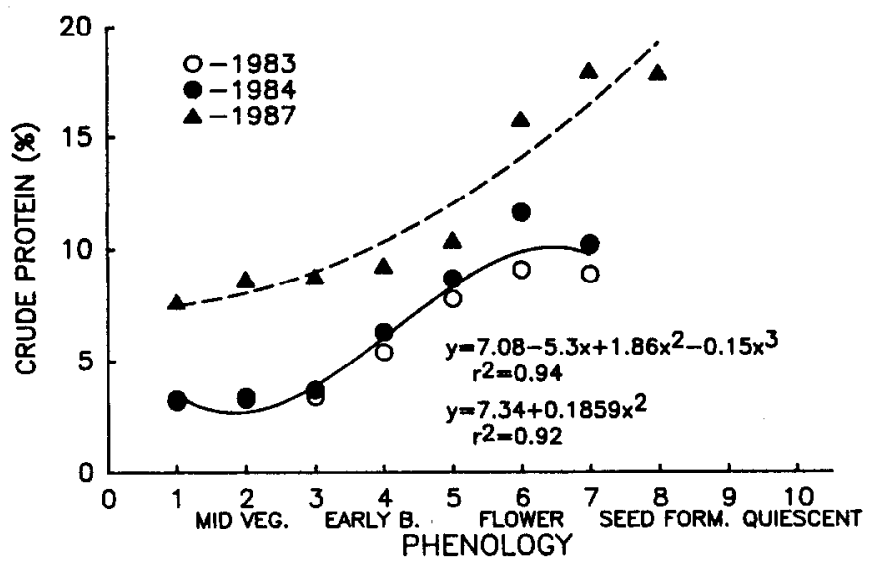

Fig. 2. Regression analysis of crude protein concentration of crested wheatgrass in mid August for regrowth accumulated after clipping once between early vegetative and seed formation stages. Phenology is on a scale of 1 to 10 as per Table 2.

Plants clipped during or after boot stage initiated new tillers if soil water was sufficient, and CP in August was at least 5.4\% (Table 4). Although plants clipped during or after boot stage increased $C P$ of regrowth clipped in August, the effect was variable, apparently being influenced in part by available soil water. The high $C P$

Table 4. Crude protein concentration of crested wheatgrass in mid-August after a single clipping at the indicated phenology.

\begin{tabular}{|c|c|c|c|c|c|}
\hline \multirow[b]{2}{*}{ Phenology } & \multicolumn{5}{|c|}{ Year } \\
\hline & 1983 & 1984 & 1985 & 1986 & 1987 \\
\hline & \multicolumn{5}{|c|}{$\ldots\left(\mathrm{CP} \% \pm \mathrm{SE}^{1}\right) \ldots \ldots$} \\
\hline early veg. & $3.3 \pm 0.08$ & $3.2 \pm 0.08$ & $3.6 \pm 0.07$ & $4.1 \pm 0.10$ & $7.7 \pm 0.35$ \\
\hline mid veg. & $3.4 \pm 0.04$ & $3.3 \pm 0.13$ & $4.0 \pm 0.13$ & $4.2 \pm 0.04$ & $8.7 \pm 0.38$ \\
\hline late veg. & $3.4 \pm 0.05$ & $3.7 \pm 0.09$ & $4.5 \pm 0.11$ & $5.1 \pm 0.08$ & $8.8 \pm 0.55$ \\
\hline early boot & $5.4 \pm 0.07$ & $6.3 \pm 0.23$ & $7.4 \pm 0.19$ & $7.0 \pm 0.10$ & $9.3 \pm 0.19$ \\
\hline late boot & $7.8 \pm 0.20$ & $8.7 \pm 0.60$ & $n r^{2}$ & $\mathrm{nr}$ & $10.4 \pm 0.45$ \\
\hline flowering & $9.1+0.63$ & $11.6 \pm 0.49$ & $\mathrm{nr}$ & $\mathrm{nr}$ & $15.8 \pm 0.53$ \\
\hline anthesis & $8.9 \pm 0.63$ & $10.2 \pm 1.09$ & $\mathrm{nr}$ & $\mathrm{nr}$ & $18.0 \pm 0.25$ \\
\hline seed form. & nr & $\mathrm{nr}$ & $\mathrm{nr}$ & $\mathbf{n r}$ & $17.9 \pm 0.43$ \\
\hline
\end{tabular}

${ }^{\mathrm{i}} \mathrm{n}=10$

${ }^{2}$ No regrowth occurred after clipping on these dates.

concentrations observed in 1987 are noteworthy; however, they are associated with a small regrowth biomass (Table 3). Although regrowth from plants clipped during anthesis in 1983 and 1987 was similar ( 72 and $75 \mathrm{~kg} / \mathrm{ha}$, respectively), CP of regrowth in 1987 was $9 \%$ greater than in 1983.

Sneva (1977) found that precipitation received between July and the following June, along with early spring temperatures, was highly correlated with regrowth dry matter accumulation. We found CP content in regrowth to be positively and highly correlated with occurrence of effective rain $(>10 \mathrm{~mm})$ in June $(r=0.98$; $\mathrm{n}=5)$ and with number of rainy days in July $(r=0.97 ; \mathrm{n}=5)$. Crop year precipitation showed a weak, negative correlation to regrowth quality $(r=-0.3 ; n=5)$.

\section{Discussion}

Crude protein in actively growing crested wheatgrass varied significantly within defined phenological stages over a 5-year period. Peak $\mathrm{CP}$ observed in vegetative growth varied $28 \%$, relatively, from 14.7 in April 1983 to $10.6 \%$ in April 1985. In an earlier study at Squaw Butte, crude protein in crested wheatgrass topgrowth was $12.5 \%$ on May 1st (Daugherty et al. 1982). Results from the present study indicate that CP can be as much as $25 \%$ lower than the value reported by those authors. 
The only crop year with below-average precipitation was 1984-85, and it followed a 3-year period in which crop year precipitation averaged $31 \%$ above normal. Changes in available soil nitrogen are reported to occur in response to precipitation fluctuations (Fisher et al. 1987, Sneva 1973a,b). In the present study, some combination of environmental factors apparently reduced nitrogen in topgrowth during 1985. Possible explanations include fluctuations in forage yield, changes in available soil nitrogen, differing soil water availability, and changes in production of root exudates. Further research is needed to determine how environment relates to changes in soil nitrogen mineralization processes and how these changes relate to protein concentration in rangeland forages.

Crude protein decreases during the growing season were consistent, except in 1987, when precipitation was above normal in July. Above-average summer precipitation prolonged growth, and improved the quality of feed for grazing livestock, as evidenced by forage CP in 1987. It is interesting to note that in 1984, growing season precipitation was above average in June, July, and August; however, late July forage protein was 3\% less than in 1987.

Precipitation in July, 1987, was the greatest amount recorded since 1936. However, since soil water availability was greatest during 1984 (Miller et al. 1990), precipitation alone may not have caused the high levels of protein measured in July, 1987. This study indicates that rates of change in crested wheatgrass crude protein are generally consistent as growing season advances, but that $\mathrm{CP}$ concentration at a given phenological stage is variable, especially in spring. Further research designed to determine the relationship between precipitation, available soil nitrogen, and forage nitrogen concentration is being initiated at this location.

Crested wheatgrass can be managed to produce high quality spring and fall forage if grazed during the boot stage. Crude protein in crested wheatgrass regrowth fluctuated each year, but usually provided greater than $6 \% \mathrm{CP}$ if clipped during boot stage. Clipping just after flowers emerged increased average CP to $12 \%$; however, in 2 out of 5 years no regrowth occurred after the boot stage.

Even though clipping at boot stage enhanced quality, our results, similar to those of Hyder and Sneva (1963), demonstrate that when soil moisture is limited, forage availability in fall may be insufficient to support livestock. Also, in the present study, maximum forage yield did not occur in the year with the greatest precipitation, illustrating that precipitation alone is not always an adequate predictor of rangeland forage yield or quality.

Medium-frame steers $(227 \mathrm{~kg}$ ) gaining about $1.0 \mathrm{~kg} /$ day require $11.4 \%$ protein in the diet (NRC 1984). Yearling steers will typically gain $0.9 \mathrm{~kg} /$ day or more during May and June, and supplementation programs have been developed for this area, based on normal seasonal declines in forage quality (Raleigh 1970). Lower crested wheatgrass CP concentration in 1985 and 1986 indicates that in some years protein may be inadequate for this class of livestock, even in April and May. Clipping before meristem elongation produced regrowth which was lower in protein and usually below requirements for mature cattle.

\section{Literature Cited}

AOAC. 1980. Official methods of analysis. 13th ed. Assoc. Off. Anal. Chem., Washington, D.C.

Bedell, T.E. 1973. Clipping effects on growth form, yield, and nutritive quality of crested wheatgrass in eastern Wyoming. Wyoming Agr. Exp. Sta. Res. J. 76.

Cook, C.W., and L.E. Harris. 1968. Nutritive value of seasonal ranges. Utah Agr. Exp. Sta. Bull 472.

Charley, J.L. 1972. The role of shrubs in nutrient cycling. p. 182-203. In: C.M. McKell et al. (ed.) Wildland shrubs-their biology and utilization, USDA Forest Serv. Gen. Tech. Rep. INT-1, Washington, DC.

Daugherty, D.A., C.M. Britton, and H.A. Turner. 1982. Grazing management of crested wheatgrass range for yearling steers. J. Range Manage. 35:347-350.

Fisher, F.M., L.W. Parker, J.P. Anderson, and W.G. Whitford. 1987. Nitrogen mineralization in a desert soil: Interaction effects of soil moisture and nitrogen fertilizer. Soil Sci. Soc. Amer. J. 51:1033-1041.

Hyder, D.N., and F.A. Sneva. 1963. Morphological and physiological factors affecting the grazing management of crested wheatgrass. Crop Sci. 3:267-271.

Lentz, R.D., and G.H. Simonson. 1986. A detailed soils inventory and associated vegetation of Squaw Butte Range Experiment Station. Special Rep. 760. Oregon Agr. Exp. Sta., Corvallis.

Mayland, H.F. 1986. Factors affecting yicld and nutritional quality of crested wheatgrass. p. 215-266. In: Johnson, K.L. (ed.). Crested wheatgrass: its values, problems, and myths. Proc. Symp. at Utah State Univ., Logan, Oct 3-7, 1983.

Malechek, J.C. 1986. Nutritional limits of crested wheatgrass for range livestock production. p. 267-272. In: Johnson, K.L. (ed.). Crested wheatgrass: its values, problems, and myths. Proc. Symp.at Utah State Univ., Logan, Oct 3-7, 1983.

Miller, R.F., M.R. Haferkamp, and R.F. Angell. 1990. Clipping date effects on soil water and regrowth in crested wheatgrass. J. Range Manage. Accepted.

Neter, J., and W. Wasserman. 1974. Applied linear statistical models. Richard D. Irwin, Inc., Homewood, Ill.

NRC. 1984. Nutrient requirements of beef cattle, sixth rev, ed. Nat. Acad. Sci. Washington, D.C.

Raleigh, R.J.1970.Symposium on pasture methods for maximum production in beef cattle: Manipulation of both livestock and forage management to give optimum production. J. Anim. Sci. 30:108-114.

Sneva, F.A. 1973a. Crested wheatgrass response to nitrogen and clipping. J. Range Manage. 26:47-50.

Sneva, F.A. 1973b. Wheatgrass response to seasonal applications of two nitrogen sources. J. Range Manage. 26:137-139.

Sneva, F.A. 1977. Correlations of precipitation and temperature with spring, regrowth, and mature crested wheatgrass yields. J. Range Manage. 30:270-275.

Steel, R.G.D., and J.H. Torrie. 1980. Principles and procedures of statistics. 2nd Ed. McGraw-Hill Book Co., Inc., New York. 